\title{
Identification of species belonging to the Bifidobacterium genus by PCR-RFLP analysis of a hsp60 gene fragment
}

Loredana Baffoni ${ }^{1 *}$, Verena Stenico ${ }^{1}$, Erwin Strahsburger ${ }^{2}$, Francesca Gaggia', Diana Di Gioia', Monica Modesto ${ }^{1}$, Paola Mattarelli ${ }^{1}$ and Bruno Biavati ${ }^{1}$

\begin{abstract}
Background: Bifidobacterium represents one of the largest genus within the Actinobacteria, and includes at present 32 species. These species share a high sequence homology of $16 \mathrm{~S}$ rDNA and several molecular techniques already applied to discriminate among them give ambiguous results.

The slightly higher variability of the hsp60 gene sequences with respect to the $16 \mathrm{~S}$ rRNA sequences offers better opportunities to design or develop molecular assays, allowing identification and differentiation of closely related species. hsp60 can be considered an excellent additional marker for inferring the taxonomy of the members of Bifidobacterium genus.

Results: This work illustrates a simple and cheap molecular tool for the identification of Bifidobacterium species. The hsp60 universal primers were used in a simple PCR procedure for the direct amplification of $590 \mathrm{bp}$ of the hsp60 sequence. The in silico restriction analysis of bifidobacterial hsp60 partial sequences allowed the identification of a single endonuclease (HaellI) able to provide different PCR-restriction fragment length polymorphism (RFLP) patterns in the Bifidobacterium spp. type strains evaluated. The electrophoretic analyses allowed to confirm the different RFLP patterns.

Conclusions: The developed PCR-RFLP technique resulted in efficient discrimination of the tested species and subspecies and allowed the construction of a dichotomous key in order to differentiate the most widely distributed Bifidobacterium species as well as the subspecies belonging to B. pseudolongum and B. animalis.
\end{abstract}

Keywords: Bifidobacterium spp, hsp60, PCR-RFLP, Taxonomy

\section{Background}

Members of the genus Bifidobacterium are Grampositive, obligate anaerobic, non-motile, non-spore forming bacteria [1], and are the most important constituents of human and animal intestinal microbiota $[2,3]$. Recently, news species of bifidobacteria have been described [4-6] and now more than 30 species have been included in this genus.

Bifidobacterium spp. can be detected in various ecological environments, such as intestines of different vertebrates and invertebrates, dairy products, dental caries and

\footnotetext{
* Correspondence: loredana.baffoni@unibo.it

'Department of Agricultural Sciences, University of Bologna, viale Fanin 42, 40127, Bologna, Italy

Full list of author information is available at the end of the article
}

sewage. Considering the increasing application of Bifidobacterium spp. as protective and probiotic cultures [7-9], and the fast enlargement of the genus, easy identification tools to discriminate new isolates are essential. Moreover, their correct taxonomic identification is of outmost importance for their use as probiotics [2]. Conventional identification and classification of Bifidobacterium species have been based on phenotypic and biochemical features, such as cell morphology, carbohydrate fermentation profiles, and polyacrylamide gel electrophoresis analysis of soluble cellular proteins [10]. In the last years several molecular techniques have been proposed in order to identify bifidobacteria. Most available bifidobacterial identification tools are based on 16S rRNA gene sequence analysis, such as ARDRA [11,12], DGGE [13] and PCR

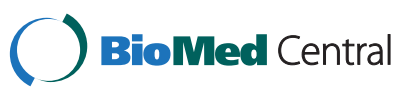




\section{Table 1 Type-strains investigated}

\begin{tabular}{|c|c|}
\hline Species & $\begin{array}{l}\text { International culture } \\
\text { collection }\end{array}$ \\
\hline Bifidobacterium adolescentis & ATCC 15703 \\
\hline Bifidobacterium angulatum & ATCC 27535 \\
\hline Bifidobacterium animalis subsp. animalis & ATCC 25527 \\
\hline Bifidobacterium animalis subsp. lactis & DSM 10140 \\
\hline Bifidobacterium asteroides & ATCC 25910 \\
\hline Bifidobacterium bifidum & ATCC 29521 \\
\hline Bifidobacterium boum & ATCC 27917 \\
\hline Bifidobacterium breve & ATCC 15700 \\
\hline Bifidobacterium catenulatum & ATCC 27539 \\
\hline Bifidobacterium choerinum & ATCC 27686 \\
\hline Bifidobacterium coryneforme & ATCC 25911 \\
\hline Bifidobacterium cuniculi & ATCC 27916 \\
\hline Bifidobacterium dentium & ATCC 27534 \\
\hline Bifidobacterium gallicum & ATCC 49850 \\
\hline Bifidobacterium gallinarum & ATCC 33777 \\
\hline Bifidobacterium indicum & ATCC 25912 \\
\hline Bifidobacterium longum subsp. longum & ATCC 15707 \\
\hline Bifidobacterium longum subsp. infantis & ATCC 15697 \\
\hline Bifidobacterium longum subsp. suis & ATCC 27533 \\
\hline Bifidobacterium minimum & ATCC 27539 \\
\hline Bifidobacterium merycicum & ATCC 49391 \\
\hline $\begin{array}{l}\text { Bifidobacterium pseudolongum subsp } \\
\text { pseudolongum }\end{array}$ & ATCC 25526 \\
\hline $\begin{array}{l}\text { Bifidobacterium pseudolongum subsp. } \\
\text { globosum }\end{array}$ & ATCC 25865 \\
\hline Bifidobacterium pseudocatenulatum & ATCC 27919 \\
\hline Bifidobacterium pullorum & ATCC 27685 \\
\hline Bifidobacterium ruminantium & ATCC 49390 \\
\hline Bifidobacterium subtile & ATCC 27537 \\
\hline $\begin{array}{l}\text { Bifidobacterium thermacidophilum subsp. } \\
\text { porcinum }\end{array}$ & LMG 21689 \\
\hline $\begin{array}{l}\text { Bifidobacterium thermacidophilum subsp. } \\
\text { thermacidophilum }\end{array}$ & LMG 21395 \\
\hline Bifidobacterium thermophilum & ATCC 25525 \\
\hline
\end{tabular}

with the use of species-specific primers [14-16]. However, 16S rDNA of Bifidobacterium spp. has a high similarity, ranging from 87.7 to $99.5 \%$ and bifidobacterial closely related species (e.g. B. catenulatum and $B$. pseudocatenulatum) or subspecies (e.g. B. longum and $B$. animalis subspecies) even possess identical $16 \mathrm{~S}$ rRNA gene sequences $[17,18]$. For this reason different molecular approaches have been tested based on repetitive genome sequences amplification, such as ERICPCR $[19,20]$, BOX-PCR $[21,22]$ or RAPD fingerprinting analysis [23]. These fingerprinting methods have the disadvantage of a low reproducibility, and they need
Table 2 List of strains investigated to confirm the conservation of RFLP profiles (strains belonging to BUSCoB collection)

\begin{tabular}{|c|c|c|}
\hline Species ${ }^{*}$ & Strain & Source \\
\hline Bifidobacterium animalis subsp. animalis & T169 & Rat \\
\hline Bifidobacterium animalis subsp. animalis & $\mathrm{T} 6 / 1$ & Rat \\
\hline Bifidobacterium animalis subsp. lactis & P23 & Chicken \\
\hline Bifidobacterium animalis subsp. lactis & F439 & Sewage \\
\hline Bifidobacterium animalis subsp. lactis & Ra20 & Rabbit \\
\hline Bifidobacterium animalis subsp. lactis & Ra18 & Rabbit \\
\hline Bifidobacterium animalis subsp. lactis & P32 & Chicken \\
\hline Bifidobacterium bifidum & B1764 & Infant \\
\hline Bifidobacterium bifidum & B2091 & Infant \\
\hline Bifidobacterium bifidum & B7613 & $\begin{array}{l}\text { Preterm } \\
\text { infant }\end{array}$ \\
\hline Bifidobacterium bifidum & B2009 & Infant \\
\hline Bifidobacterium bifidum & B2531 & Infant \\
\hline Bifidobacterium breve & B2274 & Infant \\
\hline Bifidobacterium breve & B2150 & Infant \\
\hline Bifidobacterium breve & B8279 & $\begin{array}{l}\text { Preterm } \\
\text { infant }\end{array}$ \\
\hline Bifidobacterium breve & B8179 & $\begin{array}{l}\text { Preterm } \\
\text { infant }\end{array}$ \\
\hline Bifidobacterium breve & Re1 & Infant \\
\hline Bifidobacterium catenulatum & B1955 & Infant \\
\hline Bifidobacterium catenulatum & B684 & Adult \\
\hline Bifidobacterium catenulatum & B2120 & Infant \\
\hline Bifidobacterium pseudocatenulatum & B1286 & Infant \\
\hline Bifidobacterium pseudocatenulatum & B7003 & \\
\hline Bifidobacterium pseudocatenulatum & B8452 & \\
\hline Bifidobacterium dentium & Chz7 & Chimpanzee \\
\hline Bifidobacterium dentium & Chz15 & Chimpanzee \\
\hline Bifidobacterium longum subsp.longum & PCB133 & Adult \\
\hline Bifidobacterium longum subsp. infantis & B7740 & $\begin{array}{l}\text { Preterm } \\
\text { infant }\end{array}$ \\
\hline Bifidobacterium longum subsp. infantis & B7710 & $\begin{array}{l}\text { Preterm } \\
\text { infant }\end{array}$ \\
\hline Bifidobacterium longum subsp. suis & Su864 & Piglet \\
\hline Bifidobacterium longum subsp. suis & Su932 & Piglet \\
\hline Bifidobacterium longum subsp. suis & Su905 & Piglet \\
\hline Bifidobacterium longum subsp. suis & Su908 & Piglet \\
\hline $\begin{array}{l}\text { Bifidobacterium pseudolongum subsp. } \\
\text { pseudolongum }\end{array}$ & MB9 & Chicken \\
\hline $\begin{array}{l}\text { Bifidobacterium pseudolongum subsp. } \\
\text { pseudolongum }\end{array}$ & MB10 & Mouse \\
\hline $\begin{array}{l}\text { Bifidobacterium pseudolongum subsp. } \\
\text { pseudolongum }\end{array}$ & MB8 & Chicken \\
\hline Bifidobacterium pseudolongum subsp. globosum & $\operatorname{Ra} 27$ & Rabbit \\
\hline Bifidobacterium pseudolongum subsp. globosum & VT366 & Calf \\
\hline
\end{tabular}


Table 2 List of strains investigated to confirm the conservation of RFLP profiles (strains belonging to BUSCoB collection) (Continued)

\begin{tabular}{lll}
\hline Bifidobacterium pseudolongum subsp. globosum & T19 & Rat \\
Bifidobacterium pseudolongum subsp. globosum & P113 & Chicken \\
\hline * previously assigned taxonomic identification. & &
\end{tabular}

strict standardization of PCR conditions. The use of different polymerases, DNA/primer ratios or different annealing temperatures may lead to a discrepancy in the results obtained in different laboratories [24].

In recent years alternative molecular markers have been proposed for bifidobacteria identification (e.g. hsp60, recA, tuf, atpD, dnaK) and Ventura et al. [18] developed a multilocus approach, based on sequencing results, for the analysis of bifidobacteria evolution. The hsp60 gene, coding for a highly conserved $60 \mathrm{kDa}$ heat-shock-protein (a chaperonin), has been evaluated for phylogenetic analysis in bifidobacteria by Jian et al. [25]. The sequence comparison of this gene has been already used for species identification and phylogenetic analysis of other genera (e.g. Staphylococcus, Lactobacillus) and enteric pathogens [26-28]. A chaperonin database $(\mathrm{cpnDB})$ is available on line, collecting bacterial and eukaryotic sequences (http://www.cpndb.ca/ cpnDB/home.php) [29].

Table 3 Expected fragment sizes obtained with in silico digestion of the hsp60 gene sequences

\begin{tabular}{|c|c|c|c|}
\hline Bifidobacterium species & GenBank entry & Predicted fragment sizes & Profile \\
\hline B. adolescentis & AF210319 & $31-36-81-103-339$ & \\
\hline B. angulatum & AF240568 & $42-54-59-139-296$ & \\
\hline B. animalis subsp. animalis & AY004273 & $17-53-86-97-114-223$ & \\
\hline B. animalis subsp. lactis & AY004282 & $71-86-96-114-223$ & \\
\hline B. asteroides & AF240570 & 30-38-75-97-109-242 & \\
\hline B. bifidum & AY004280 & $22-31-59-181-297$ & \\
\hline B. boum & AY004285 & $22-117-200-251$ & \\
\hline B. breve & AF240566 & $106-139-139-200$ & \\
\hline B. catenulatum & AY004272 & 53-198-338 & \\
\hline B. choerinum & AY013247 & $36-42-51-52-54-59-97-200$ & \\
\hline B. coryneforme & AY004275 & $16-32-54-158-338$ & \\
\hline B. cuniculi & AY004283 & $16-42-53-70-128-281$ & \\
\hline B. dentium & AF240572 & $22-31-42-68-130-139-158$ & \\
\hline B. gallicum & AF240575 & $42-253-297$ & \\
\hline B. gallinarum & AY004279 & $16-31-42-81-139-281$ & \\
\hline B. indicum & AF240574 & $16-32-36-42-45-123-296$ & \\
\hline B. longum subsp. longum & AF240578 & 42-113-138-139-158 & * \\
\hline B. longum subsp. infantis & AF240577 & $42-113-138-139-158$ & * \\
\hline B. longum subsp. suis & AY013248 & 42-113-138-139-158 & * \\
\hline B. merycicum & AY004277 & $22-31-42-59-139-297$ & \\
\hline B. minimum & AY004284 & $16-51-60-66-70-327$ & \\
\hline B. pseudocatenulatum & AY004274 & $42-53-198-297$ & \\
\hline B. pseudolongum subsp pseudolongum & AY004282 & $17-22-30-32-42-42-109-297$ & \\
\hline B. pseudolongum subsp. globosum & AF286736 & $16-17-22-30-32-42-109-323$ & \\
\hline B. pullorum & AY004278 & $16-31-36-42-81-87-297$ & \\
\hline B. ruminantium & AF240571 & 31-106-114-339 & \\
\hline B. subtile & Not available & Not avaiable & + \\
\hline B. thermacidophilum subsp porcinum & AY004276 & $20-42-53-59-97-139-180$ & ${ }^{*}+$ \\
\hline B. thermacidophilum subsp thermacidophilum & AY004276 & 20-42-53-59-97-139-180 & ${ }^{*}+$ \\
\hline B. thermophilum & AF240567 & $54-59-117-139-222$ & \\
\hline
\end{tabular}

+ hsp60 sequence of $B$. subtile type strain was not available in the press-time.

$\dagger$ the available sequences at GeneBank and cpnDB belonged to B. thermacidophilum (with no distinction in subspecies)

*subspecies not discernable. 


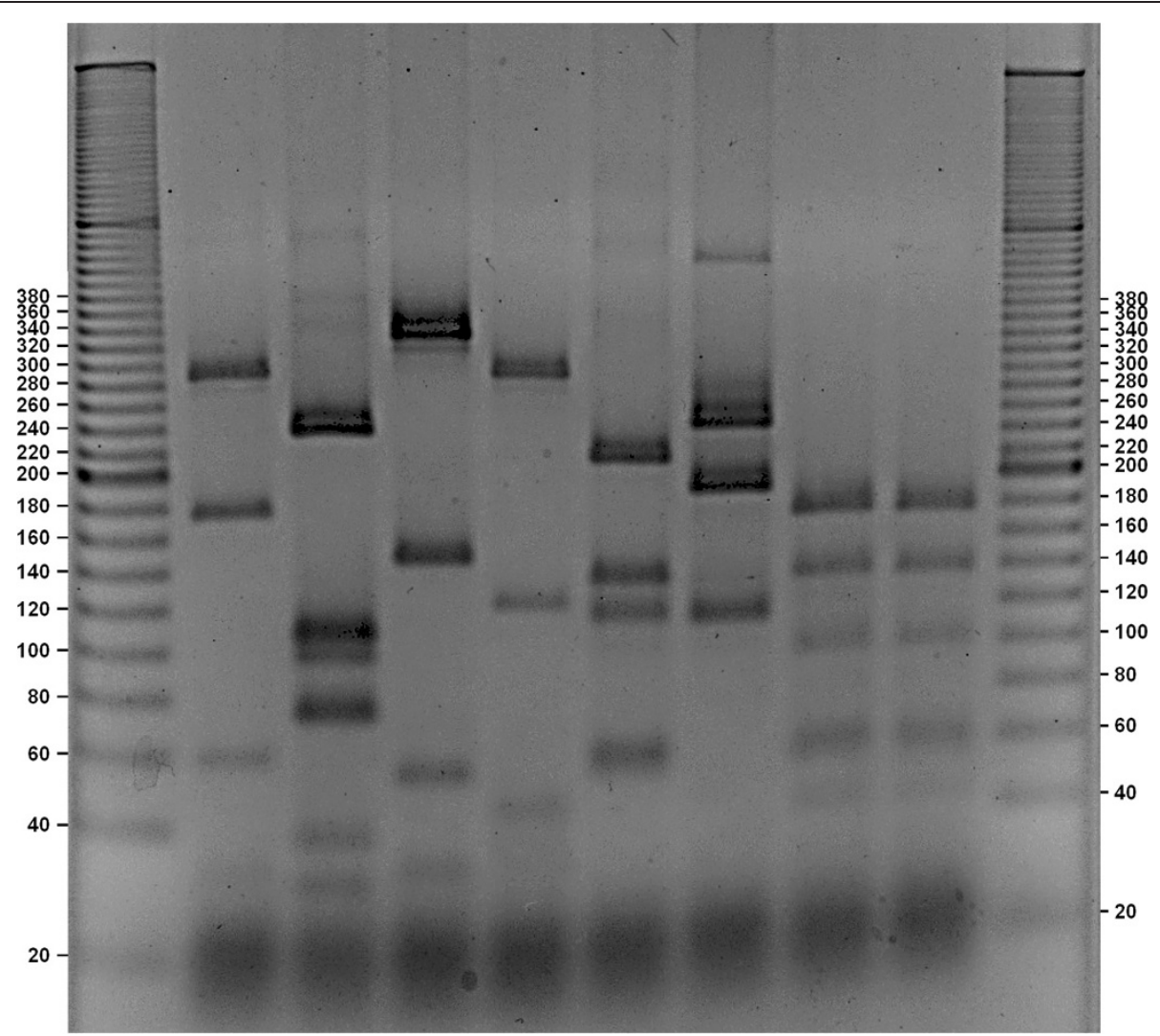

Figure 1 Agarose gel electrophoresis of digested $h s p 60$ DNA fragments with Haell (negative image). Lane1, ladder 20 bp (Sigma-Aldrich); Lane 2, B. bifidum ATCC 29521; Lane 3, B. asteroides ATCC 25910, Lane 4, B. coryneforme ATCC 25911; Lane 5, B. indicum ATCC 25912; Lane 6, B. thermophilum ATCC 25525; Lane 7, B. boum ATCC 27917; Lane 8, B. thermacidophilum subsp. porcinum LMG 21689; Lane 9, B. thermacidophilum subsp. thermacidophilum LMG 21395; Lane 10, ladder 20 bp (Sigma-Aldrich).

The purpose of this study is the development of a rapid, reproducible and easy-to-handle molecular tool for the identification of Bifidobacterium species isolated from various environments. The protocol is based on the restriction endonuclease analysis of the PCR-amplified $h s p 60$ partial gene sequence ( $h s p 60$ PCR-RFLP) with the use of a single restriction enzyme and has been tested on the 30 most widely distributed Bifidobacterium species and subspecies. A diagnostic dichotomous key to speed up profile interpretation has also been proposed.

\section{Methods}

\section{Bacterial strains and culture conditions}

The type strains used to develop the technique are listed in Table 1, whereas the strains used to validate the method are reported in Table 2. The strains, belonging to BUSCoB (Bologna University Scardovi Collection of Bifidobacteria) collection, were isolated from faeces of human and animals and from sewage. Bacteria were maintained as frozen stocks at $-80^{\circ} \mathrm{C}$ in the presence of skim milk as cryoprotective agent. Working cultures were prepared in TPY medium [1], grown anaerobically at $37^{\circ} \mathrm{C}$ and harvested at logarithmic phase.

\section{In silico analysis}

An in silico analysis was performed for the evaluation of a suitable restriction enzyme. Available hsp60 sequences had been retrieved from cpnDB database and GeneBank, thanks to the work of Jian et al. [25]. In silico digestion analysis was carried out on fragments amplified by universal primers H60F-H60R [30] using two on-line free software: webcutter 2.0 (http://rna.lundberg.gu.se/cutter2) and http://insilico.ehu.es/restriction softwares [31]. Blunt end, frequent cutter enzymes that recognize not degenerated sequences have been considered in order to find a suitable enzyme for all the species (e.g. RsaI, HaeIII, AluI, AccII). However in silico analysis had been performed also on sticky end enzymes (e.g. AatII, Sau3AI, PvuI).

\section{DNA extraction from pure cultures}

$10 \mathrm{ml}$ of culture were harvested and washed twice with TE buffer (10 mM Tris-HCl, $1 \mathrm{mM}$ EDTA, $\mathrm{pH}$ 7.6), resuspended in $1 \mathrm{ml} \mathrm{TE}$ containing $15 \mathrm{mg}$ lysozyme and incubated at $37^{\circ} \mathrm{C}$ overnight. Cells were lysed with $3 \mathrm{ml}$ of lysis buffer $(100 \mathrm{mM}$ Tris- $\mathrm{HCl}, 400 \mathrm{mM} \mathrm{NaCl}, 2 \mathrm{mM}$ EDTA, $\mathrm{pH}$ 8.2), $220 \mu \mathrm{l} \operatorname{SDS}(10 \% \mathrm{w} / \mathrm{v})$ and $150 \mu \mathrm{l}$ 


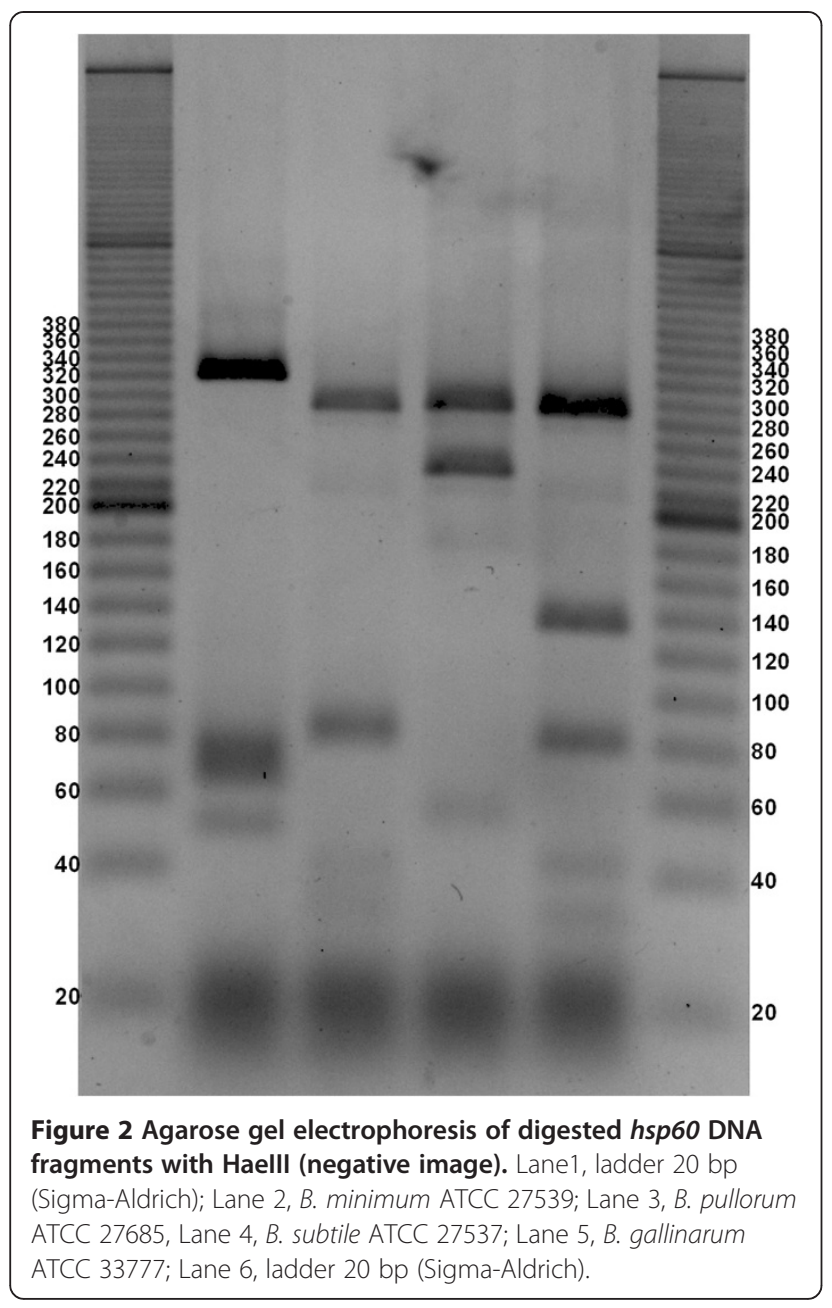

proteinase $\mathrm{K}$ (>600 $\mathrm{mAU} / \mathrm{ml}$, solution) and incubated for 2 hours in water bath at $60^{\circ} \mathrm{C}$. One $\mathrm{ml}$ of saturated $\mathrm{NaCl}$ solution was added and the suspension was gently inverted twice. Pellets were harvested through centrifugation $(5000 \times \mathrm{g})$ at room temperature for 15 minutes. After the transfer of clean supernatants in new tubes, DNA was precipitated with 2.5 volumes of cold ethanol (95\%) and resuspended in $300 \mu \mathrm{l}$ of TE buffer [32].

\section{Amplification of gene $h s p 60$ and restriction with Haelll}

Universal primers were used to amplify approximately $600 \mathrm{bp}$ of the $h s p 60$ gene in the Bifidobacterium spp. investigated. These primers H60F (5'-GG(ATGC)GA(CT)GG (ATGC)AC(ATGC)AC(ATGC)AC(ATGC)GC(ATGC)A C(ATGC)GT-3') and H60R (5'-TC(ATGC)CC(AG)AA (ATGC)CC(ATGC)GG(ATGC)GC(CT)TT(ATGC)AC (ATGC)GC-3') were designed by Rusanganwa et al. [30] on the basis of the conserved protein sequences GDGTTATV and AVKAPGFGD in HSP60. Amplifications were performed in $20 \mu \mathrm{l}$ volumes with $1.5 \mu \mathrm{M}$ of each primer (Eurofins MWG Operon, Ebersberg, Germany), $10 \mu \mathrm{l} 2 \mathrm{X}$ HotStarTaq Plus Master Mix (Qiagen, Italy) (1,5 mM

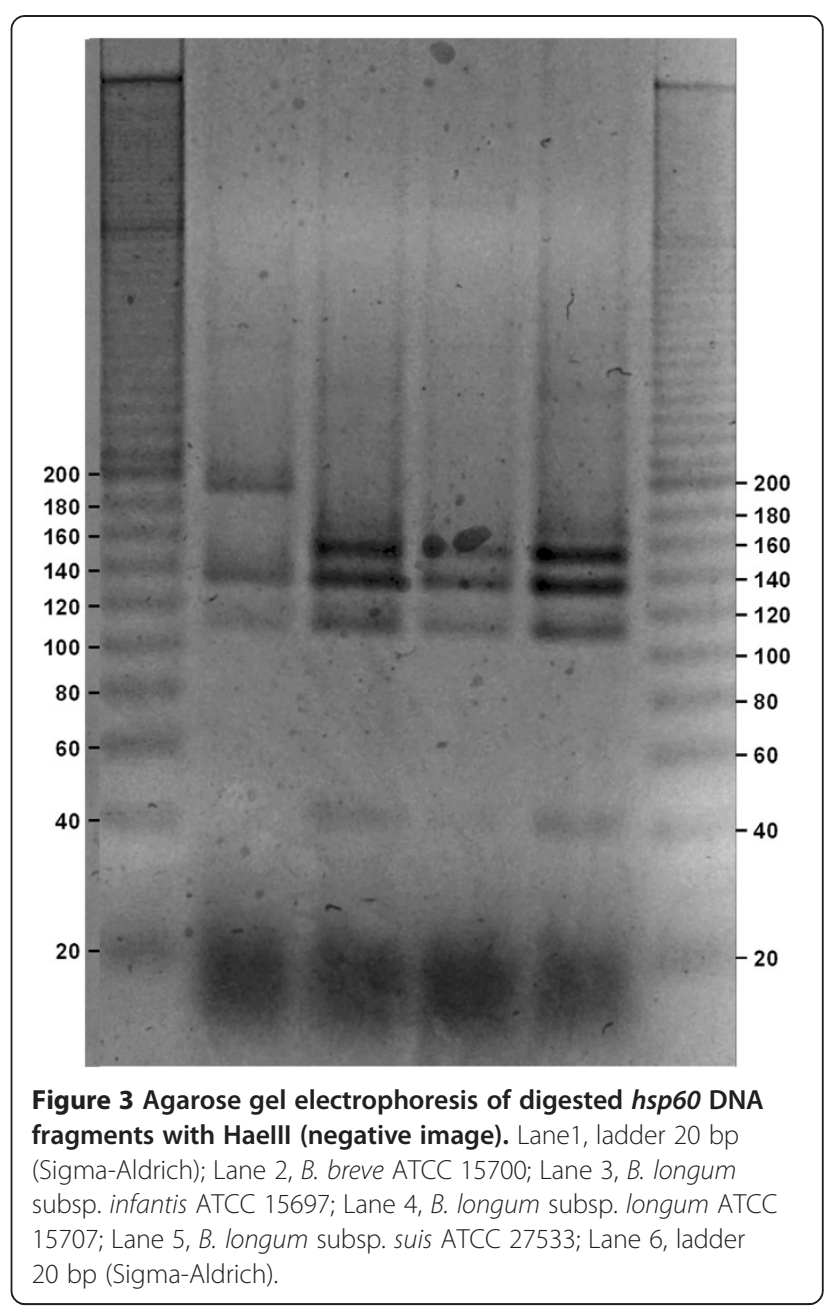

$\mathrm{MgCl}_{2}, 1 \mathrm{U}$ Taq, $0.2 \mathrm{mM} \mathrm{dNTP}$, final concentration) and $150 \mathrm{ng} / \mu \mathrm{l}$ DNA. The PCR cycle consisted of an initial denaturation of $5 \mathrm{~min}$ at $95^{\circ} \mathrm{C}$ followed by 35 cycles of denaturation $\left(30 \mathrm{~s}\right.$ at $\left.94^{\circ} \mathrm{C}\right)$, annealing $\left(30 \mathrm{~s}\right.$ at $\left.61^{\circ} \mathrm{C}\right)$ and extension $\left(45 \mathrm{~s}\right.$ at $\left.72^{\circ} \mathrm{C}\right)$. The PCR was completed with a final elongation of $10 \mathrm{~min}$ at $72^{\circ} \mathrm{C}$. The PCR amplification was performed with a PCR Verity 96-well thermal cycler (Applied Biosystems, Milan, Italy). After amplification, the product was visualized via agarose gel $(1.3 \% \mathrm{w} / \mathrm{v})$ in $1 \mathrm{X}$ TBE buffer and visualized with ethidium bromide under UV light. A 100 bp DNA ladder (Sigma-Aldrich) was used as a DNA molecular weight marker. Bands were excised from agarose gel (Additional file 1: Figure S1) and DNA was eluted with NucleoSpin ${ }^{\circledR}$ Gel and PCR Clean-up (Macherey-Nagel GmbH \& Co. KG, Germany) in order to avoid possible non-specific amplifications. $3 \mu \mathrm{l}$ of the eluted DNA was re-amplified in a $30 \mu \mathrm{l}$ PCR reaction (see above). BSA was added to the reaction $(5 \% \mathrm{v} / \mathrm{v}$, Fermentas). The PCR products $(2 \mu \mathrm{l})$ were checked for non-specific amplification on agarose gel. $20 \mu \mathrm{l}(\sim 6 \mu \mathrm{g})$ of PCR amplicons were digested with HaelII enzyme. Restriction digestion was carried out for $2 \mathrm{~h}$ at $37^{\circ} \mathrm{C}$ in $30 \mu \mathrm{l}$ 


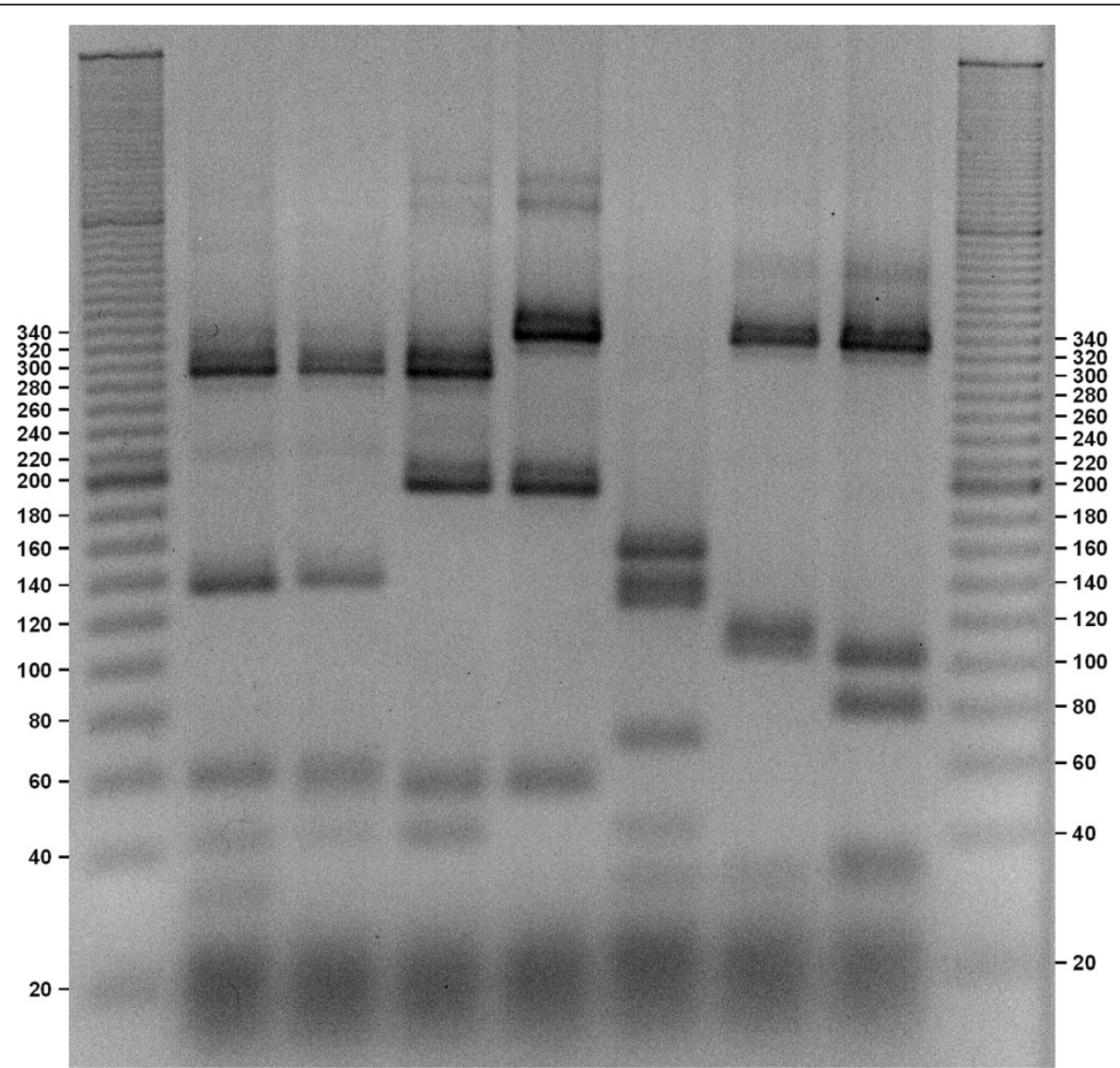

Figure 4 Agarose gel electrophoresis of digested $\boldsymbol{h s p 6 0}$ DNA fragments with Haelll (negative image). Lane1, ladder 20 bp (Sigma-Aldrich); Lane 2, B. merycicum ATCC 49391; Lane 3, B. angulatum ATCC 27535, Lane 4, B. pseudocatenulatum ATCC 27919; Lane 5, B. catenulatum ATCC 27539; Lane 6, B. dentium ATCC 27534; Lane 7, B. ruminantium ATCC 49390; Lane 8, B. adolescentis ATCC 15703; Lane 9, ladder 20 bp (Sigma-Aldrich).

reaction mixture with 1X SM Restriction Buffer (SigmaAldrich), $1.5 \mu \mathrm{l}$ HaeIII (10 U/ $\mu$ l, Sigma-Aldrich) and water. Digestion products were stained with ethidium bromide and visualized under UV-light (GelDoc ${ }^{\mathrm{Tx}}$, BioRad), after agarose gel electrophoresis $(3.0 \%$ agarose $(w / v)$, TBE $1 X)$ at $210 \mathrm{~V}(3 \mathrm{~h})$. A $20 \mathrm{bp}$ DNA ladder (Sigma-Aldrich) was used. The obtained pictures were elaborated with a free software GNU Image Manipulation Program (Gimp 2.8) only to invert colors and increase contrast.

Precast gradient polyacrylamide gels (4-20\%) (Lonza Group Ltd, Switzerland) were also used to obtain RFLP profiles, in order to have a comparison with agarose gels. The vertical electrophoresis apparatus used was P8DS ${ }^{\text {Tx }}$ Emperor Penguin (Owl, Thermo Scientific) with an adaptor for Lonza precast gels. The run was performed at $100 \mathrm{~V}$ in TBE $1 \mathrm{X}$.

\section{Diagnostic key}

A dichotomous key was developed comparing in silico digestion results and the evaluation of visible bands with the use of ImageLab 2.0 software (Bio-Rad Laboratories, Inc.).

\section{Results and discussion}

\section{In silico analysis}

The analysis and comparison of restriction profiles obtained with in silico digestion of bifidobacterial hsp 60 sequences allowed the identification of a set of appropriate frequent-cutter endonucleases that recognize non degenerated sequences. The restriction enzyme HaeIII was found to give the clearest and most discriminatory profiles in theoretical PCR-RFLP patterns, discriminating the majority of Bifidobacterium type-strains tested (Table 3). Furthermore, the profiles of other strains, belonging to the investigated species, have been analyzed to confirm the conservation of RFLP profiles within species.

\section{Amplification and restriction analysis of Bifidobacterium spp.}

Theoretical restriction profiles have been confirmed in vitro on agarose gel. The obtained fragments ranged from $16 \mathrm{bp}$ to $339 \mathrm{bp}$ (Table 3). Fragments lower than $25 \mathrm{bp}$ were not considered as they did not help in species discrimination and in addition they co-migrate with 


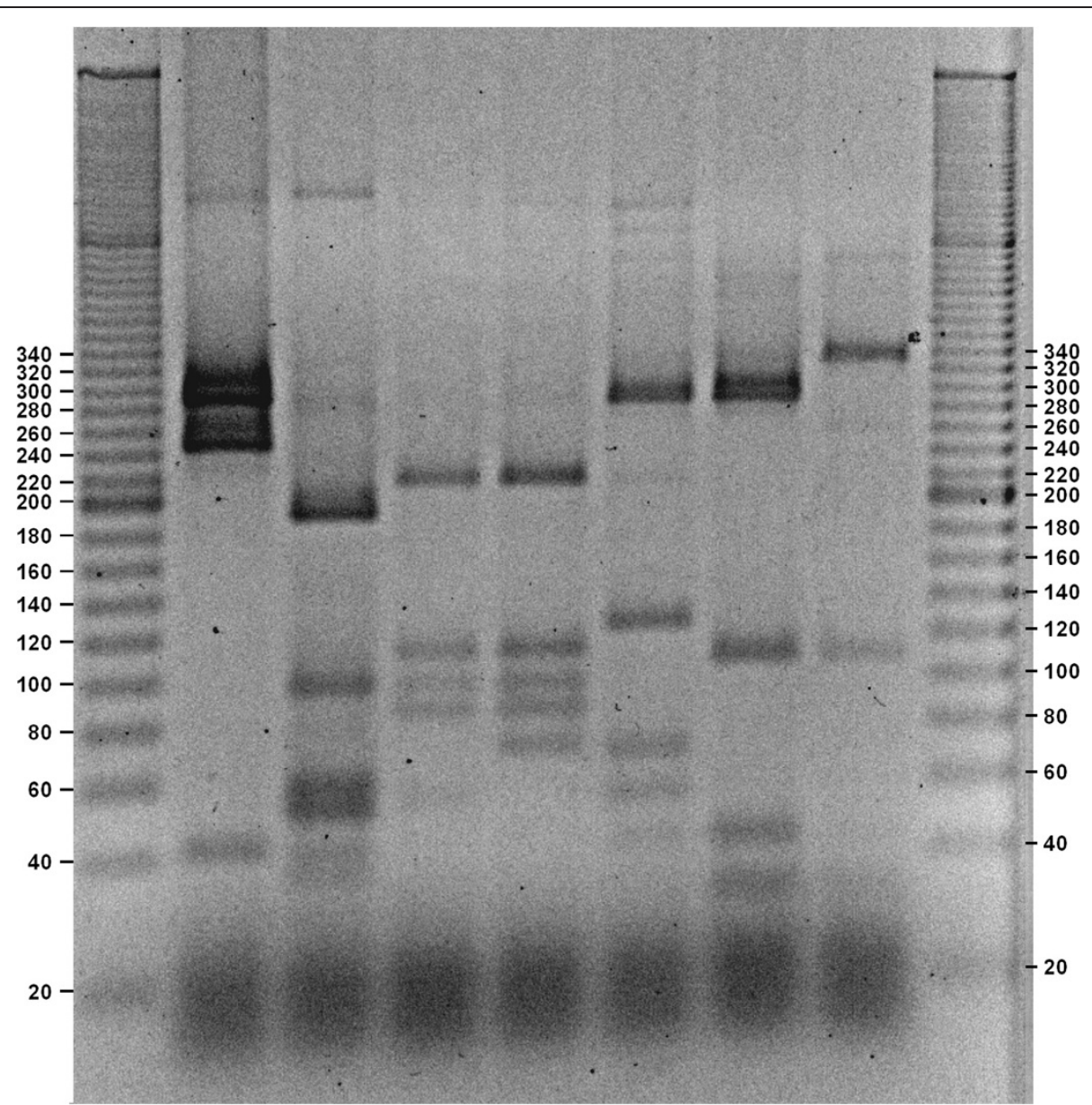

Figure 5 Agarose gel electrophoresis of digested $h s p 60$ DNA fragments with Haelll (negative image). Lane1, ladder 20 bp (Sigma-Aldrich); Lane 2, B. gallicum ATCC 49850; Lane 3, B. choerinum ATCC 27686, Lane 4, B. animalis subsp. lactis DSM 10140; Lane 5, B. animalis subsp. animalis ATCC 25527; Lane 6, B. cuniculi ATCC 27916; Lane 7, B. pseudolongum subsp. pseudolongum ATCC 25526; Lane 8, B. pseudolongum subsp. globosum ATCC 25865; Lane 9, ladder 20 bp (Sigma-Aldrich).

primers. Time course analysis of restricted samples showed the formation of a band of $\sim 200 \mathrm{bp}$ in several species due to an over-digestion (data not shown) and this invalidated the RFLP profiles. For this reason the protocol has been optimized at 2 hours restriction time. Fragments greater than 360 bp were also not considered due to a possible incomplete digestion of such long fragments.

The obtained gels (Figures 1, 2, 3, 4 and 5) show species-specific profiles for all type-strains other than $B$. longum and $B$. thermacidophilum subspecies. This technique does not allow the identification of the subspecies belonging to these species, which displayed identical RFLP profiles. Matsuki et al. $[14,17]$ proposed specific primers to differentiate the subspecies of the species B. longum, while B. thermacidophilum subsp. porcinum and B. thermacidophilum subsp. thermacidophilum can be differentiated according to $\mathrm{Zhu}$ et al. [33]. The proposed restriction analysis is efficient in discriminating very closely related species and subspecies as B. catenulatum/ B. pseudocatenulatum, B. pseudolongum subsp. pseudolongum/ $B$. pseudolongum subsp. globosum and B. animalis subsp. animalis/B. animalis. subsp. lactis.

The same method has been applied with the use of precast gradient polyacrylamide gels. The resolution was greater than that obtained on agarose gels, loading only $4 \mu \mathrm{l}$ of the restriction reaction instead of the $30 \mu \mathrm{l}$ used in horizontal electrophoresis. This may allow to reduce the volume of amplification reactions with a consequent reduction of costs.

The comparison between in silico digestion and the obtained gel profiles allowed to develop a dichotomous key (Figure 6) for a faster interpretation of the restriction profiles.

Validation of PCR-RFLP analysis on bifidobacterial isolates 39 strains belonging to 12 different species/subspecies (Table 2) have been investigated to validate the PCR- 


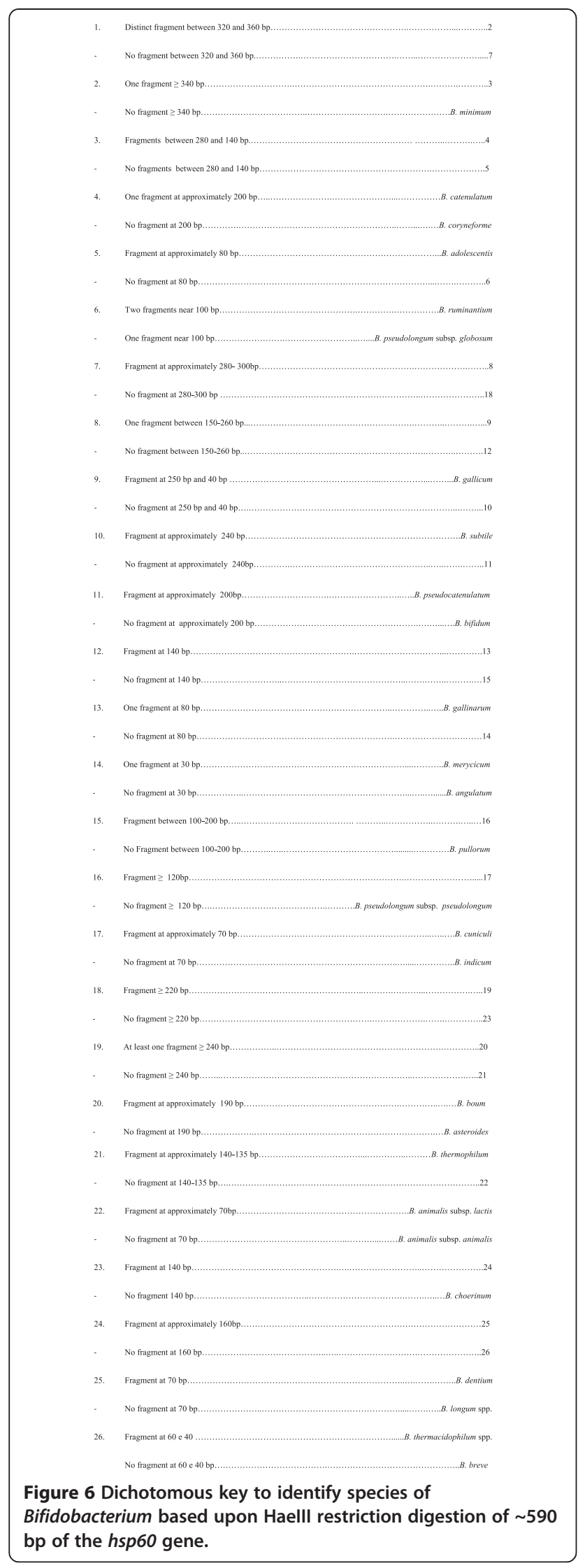

RFLP technique. Most of the strains tested were previously identified using biochemical tests and in some cases also molecular techniques (species-specific PCR, 16S rDNA sequencing). The obtained data confirmed a conservation of the profiles concerning the species and subspecies tested. Two figures are available as Additional files (Additional file 2: Figure S2: strains belonging to $B$. animalis subsp. lactis and $B$. animalis subsp. animalis. Additional file 3: Figure S3: strains belonging to $B$. longum subsp. longum, B. longum subsp. infantis, B. longum subsp. suis). About $95 \%$ of the strains confirmed the taxonomic identification previously assigned. Two strains, B1955 and Su864, previously classified as B. catenulatum and $B$. longum subsp. suis respectively, gave different profiles from those expected. The RFLP profiles of B1955 turned out to be the same of B. adolescentis ATCC 15703 (T), the dichotomous key confirmed the assignment to the $B$. adolescentis species. In addition, Su864 was identified as a $B$. breve strain. These results were also verified through a species-specific PCR [14].

\section{Conclusions}

In this work a PCR-RFLP based method to identify Bifidobacterium spp. was developed and tested on strains belonging to different species. The technique could efficiently differentiate all the 25 species of Bifidobacterium genus and the subspecies belonging to $B$. pseudolongum and $B$. animalis, with the support of an easy-to-handle dichotomous key. The technique turned out to be fast and easy, and presented a potential value for a rapid preliminary identification of bifidobacterial isolates.

\section{Additional files}

Additional file 1: Figure S1. Example of agarose gel electrophoresis of hsp60 amplicons from different bifidobacterial strains.

Additional file 2: Figure S2. Agarose gel electrophoresis of digested hsp60 DNA fragments with Haelll (negative image). Lane1, ladder $20 \mathrm{bp}$ (Sigma-Aldrich); Lane 2-6, B. animalis subsp.lactis strains Ra20, Ra18, F439, P23, P32; Lane 7-8, B. animalis subsp. animalis strains T169, T6/1; Lane 9, ladder 20 bp (Sigma-Aldrich).

Additional file 3: Figure S3. Agarose gel electrophoresis of digested hsp60 DNA fragments with Haelll (negative image). Lane1, ladder 20 bp (Sigma-Aldrich); Lane 2-4, B. longum subsp. suis strains Su864, Su908, Su932; Lane 5-6, B. longum subsp. longum strains PCB133, ATCC 15707 (T); Lane 7-9, B. longum subsp. infantis strains ATCC 15697 (T), B7740, B7710; Lane 9, ladder 20 bp (Sigma-Aldrich).

\section{Abbreviations}

PCR: Polymerase chain reaction; RFLP-PCR: Restriction fragment length polymorphism; HSP60: Heat-shock protein 60; rDNA: Ribosomal DNA; ARDRA: Amplified ribosomal DNA restriction analysis; DGGE: Denaturing gradient gel electrophoresis; ERIC-PCR: Enterobacterial repetitive intergenic consensus-PCR; RAPD: Random amplified polymorphic DNA; cpnDB: Chaperonin database; TPY medium: Tryptone phytone, yeast medium; BUSCoB: (Bologna University Scardovi Collection of Bifidobacteria).

\section{Competing interests}

The authors declare that they have no competing interests. 


\section{Authors' contributions}

LB conceived the study. LB, VS and ES carried out all the bioinformatics, RFLP analyses, DNA extractions and culture handling. VS conceived the dichotomous key. MM and PM provided some of the strains tested together with the extracted DNA. DDG and FG supervised the work. LB, VS, DDG and FG contributed to paper writing. All authors read and approved the final manuscript. BB supported the research.

\section{Author details}

'Department of Agricultural Sciences, University of Bologna, viale Fanin 42, 40127, Bologna, Italy. ${ }^{2}$ Laboratorio de Microbiología Molecular y Biotecnología Ambiental, Departamento de Química and Center of Nanotechnology and Systems Biology, Universidad Técnica Federico Santa María, Avenida España 1680, Valparaíso, Chile.

Received: 20 February 2013 Accepted: 27 May 2013

Published: 1 July 2013

\section{References}

1. Biavati B, Mattarelli P: Genus Bifidobacterium. In Bergey's Manual of systematic bacteriology. Volume 5 2nd edition. Edited by Goodfellow M, Kampfer P, Busse H-J, Suzuki K-I, Ludwig W, Whitman WB. New York: Springer; 2012:171-206.

2. Gaggia F, Mattarelli P, Biavati B: Probiotics and prebiotics in animal feeding for safe food production. Int J Food Microbiol 2010, 141:S15-S28.

3. Turroni F, Ribbera A, Foroni E, van Sinderen D, Ventura M: Human gut microbiota and bifidobacteria: from composition to functionality. Antonie Van Leeuwenhoek 2008, 94:35-50.

4. Endo A, Futagawa-Endo Y, Schumann P, Pukall R, Dicks LM: Bifidobacterium reuteri sp. nov., Bifidobacterium callitrichos sp. nov., Bifidobacterium saguini sp. nov., Bifidobacterium stellenboschense sp. nov. and Bifidobacterium biavatii sp. nov. isolated from faeces of common marmoset (Callithrix jacchus) and red-handed tamarin (Saguinus midas), Syst Appl Microbiol 2012, 35:92-97.

5. Kim MS, Roh SW, Bae JW: Bifidobacterium stercoris sp. nov., isolated from human faeces. Int I Syst Evol Microbiol 2010, 60:2823-2827.

6. Morita H, Nakano A, Onoda H, Toh H, Oshima K, Takami H, Murakami M, Fukuda S, Takizawa T, Kuwahara T, Ohno H, Tanabe S, Hattori M: Bifidobacterium kashiwanohense sp. nov., isolated from healthy infant faeces. Int J Syst Evol Microbiol 2011, 61:2610-2615.

7. Aloisio I, Santini C, Biavati B, Dinelli G, Cencič A, Chingwaru W, Mogna L, Di Gioia D: Characterization of Bifidobacterium spp. strains for the treatment of enteric disorders in newborns. App Microbiol Biotechnol 2012, 96(6):1561-1576.

8. Baffoni L, Gaggìa F, Di Gioia D, Santini C, Mogna L, Biavati B: A Bifidobacteriumbased synbiotic product to reduce the transmission of $C$. jejuni along the poultry food chain. Int J Food Microbiol 2012, 157(2):156-161.

9. Gaggia F, Di Gioia D, Baffoni L, Biavati B: The role of protective and probiotic cultures in food and feed and their impact in food safety. Trends Foods Sci Tech 2011, 22:58-66.

10. Biavati B, Castagnoli P, Trovatelli LD: Species of the genus Bifidobacterium in the feces of human adults. Microbiologica 1986, 9:39-45.

11. Krízová J, Spanová A, Rittich B: Evaluation of amplified ribosomal DNA restriction analysis (ARDRA) and species-specific PCR for identification of Bifidobacterium species. Syst Appl Microbiol 2006, 29:36-44

12. Ventura M, Elli M, Reniero R, Zink R: Molecular microbial analysis of Bifidobacterium isolates from different environments by the speciesspecific amplified ribosomal DNA restriction analysis (ARDRA). FEMS Microbiol Ecol 2001, 36:113-121.

13. Temmerman R, Masco L, Vanhoutte T, Huys G, Swings J: Development and validation of a nested-PCR-denaturing gradient gel electrophoresis method for taxonomic characterization of bifidobacterial communities. Appl Environ Microbiol 2003, 69:6380-6385.

14. Matsuki T, Watanabe K, Tanaka R, Oyaizu H: Rapid identification of human intestinal bifidobacteria by $16 \mathrm{~S}$ rRNA-targeted species- and groupspecific primers. FEMS Microbiol Lett 1998, 167:113-121.

15. Matsuki T, Watanabe K, Tanaka R, Fukuda M, Oyaizu H: Distribution of bifidobacterial species in human intestinal microflora examined with $16 \mathrm{~S}$ rRNA-gene-targeted species-specific primers. Appl Environ Microbiol 1999, 65:4506-4512.

16. Matsuki T, Watanabe K, Fujimoto J, Kado Y, Takada T, Matsumoto K, Tanaka R: Quantitative PCR with 16S rRNA-gene-targeted species-specific primers for analysis of human intestinal bifidobacteria. Appl Environ Microbiol 2004, 70:167-173.

17. Matsuki T, Watanabe K, Tanaka R: Genus- and species-specific PCR primers for the detection and identification of bifidobacteria. Curr Issues Intest Microbiol 2003, 4:61-69.

18. Ventura M, Canchaya C, Del Casale A, Dellaglio F, Neviani E, Fitzgerald GF, van Sinderen D: Analysis of bifidobacterial evolution using a multilocus approach. Int J Syst Evol Microbiol 2006, 56:2783-2792.

19. Shuhaimi M, Ali AM, Saleh NM, Yazid AM: Utilisation of enterobacterial repetitive intergenic consensus (ERIC) sequence-based PCR to fingerprint the genomes of Bifidobacterium isolates and other probiotic bacteria. Biotech Lett 2001, 23:731-736.

20. Ventura M, Meylan V, Zink R: Identification and tracing of Bifidobacterium species by use of enterobacterial repetitive intergenic consensus sequences. Appl Environ Microbiol 2003, 69:4296-4301.

21. Gómez Zavaglia A, de Urraza P, De Antoni G: Characterization of Bifdobacterium strains using Box primers. Anaerobe 2000, 6:169-177.

22. Masco L, Huys G, Gevers D, Verbrugghen L, Swings J: Identification of Bifidobacterium species using rep-PCR fingerprinting. Syst App/ Microbiol 2003, 26:557-563.

23. Vincent $D$, Roy D, Mondou F, Déry C: Characterization of bifidobacteria by random DNA amplification. Int J Food Microbiol 1998, 43:185-193.

24. Sidarenka AV, Novik Gl, Akimov VN: Application of molecular methods to classification and identification of bacteria of the genus Bifidobacterium. Microbiology 2008, 77:251-260.

25. Jian W, Zhu L, Dong X: New approach to phylogenetic analysis of the genus Bifidobacterium based on partial HSP60 gene sequences. Int I Syst Evol Microbiol 2001, 51:1633-1638

26. Blaiotta G, Fusco V, Ercolini D, Aponte M, Pepe O, Villani F: Lactobacillus strain diversity based on partial $h s p 60$ gene sequences and design of PCR-Restriction Fragment Length Polymorphism assays for species identification and differentiation. Appl Environ Microbiol 2008, 74:208-215.

27. Goh SH, Potter S, Wood JO, Hemmingsen SM, Reynolds RP, Chow AW: HSP60 gene sequences as universal targets for microbial species identification: studies with coagulase-negative staphylococci. J Clin Microbiol 1996, 34:818-823.

28. Wong RS, Chow AW: Identification of enteric pathogens by heat shock protein 60kDa (HSP60) gene sequences. FEMS Microbiol Lett 2002, 206:107-113.

29. Hill JE, Penny SL, Crowell KG, Goh SH, Hemmingsen SM: cpnDB: a chaperonin sequence database. Genome Res 2004, 14:1669-1675.

30. Rusanganwa E, Singh B, Gupta RS: Cloning of HSP60 (GroEL) operon from Clostridium perfringens using a polymerase chain reaction based approach. Biochim Biophys Acta 1992, 1130:90-94.

31. Bikandi J, San Millán R, Rementeria A, Garaizar J: In silico analysis of complete bacterial genomes: PCR, AFLP-PCR, and endonuclease restriction. Bioinformatics 2004, 20:798-799.

32. Rossi M, Altomare L, Rodriguez AG, Brigidi P, Matteuzzi D: Nucleotide sequence, expression and transcriptional analysis of the Bifidobacterium longum MB219 lacZ gene. Arch Microbiol 2000, 174:74-80.

33. Zhu L, Li W, Dong X: Species identification of genus Bifidobacterium based on partial HSP60 gene sequences and proposal of Bifidobacterium thermacidophilum subsp porcinum subsp nov. Int I Syst Evol Microbiol 2003, 53:1619-1623.

doi:10.1186/1471-2180-13-149

Cite this article as: Baffoni et al: Identification of species belonging to the Bifidobacterium genus by PCR-RFLP analysis of a hsp60 gene fragment. BMC Microbiology 2013 13:149. 